\title{
A bizalom és etika igénye a digitális korszakban - Napfény és árnyék a FinTech világában*
}

\author{
Müller János - Kerényi Ádám
}

A negyedik ipari forradalom részeként, a nemzetközi pénzügyi válságot követően általános támogatás, fogyasztói elégedettség mellett megjelenő digitális pénzügyi FinTech-szolgáltatások olyan szakaszba értek, amely megbonthatja a hagyományos pénzügyi struktúrákat. A FinTech-startupok szerepét korábban a bankok-amelyek akkoriban a bizalmi tőkéjük helyreállításával és müködésük optimalizálásával voltak elfoglalva -, valamint a szabályozók, felügyelők marginálisnak, kockázatmentesnek tekintették. A FinTech térhódítása azonban forradalmian gyors és ma már több típusú pénzügyi stabilitási kockázatot, komoly veszélyforrást jelent. A potenciális pénzügyi stabilitási problémák elhárítása érdekében megjelent a FinTech nemzeti és nemzetközi szabályozásának igénye, ideértve a FinTech-ek által felhalmozott és felhasznált adattömeg kezelését is. Olyan helyzet alakult ki, amikor a nemzetközi és nemzeti színtéren három követelménynek kellene eleget tenni: a digitális, FinTech-folyamatok támogatásának, a hagyományos bankok és a FinTech/BigTech vállalkozások közötti egyenlö versenyfeltételek biztosításának, és a FinTech típusú szolgáltatások nemzetközi és nemzeti szabályozásának. Az első kivételével e követelmények eddig nem teljesültek, áthidaló megoldásként elötérbe kerültek az etikai, bizalmi elvárások, kódexek. Ezért vizsgálatunk központi témája a bizalom és az etika követelményrendszerének fontossága a bankrendszerben, érvényesülése a FinTech világában. Bemutatjuk, hogy a bizalom építéséhez miért válik szükségessé a magatartási kódexek, a kötelező gondosság és etikai normák bevezetése.

Journal of Economic Literature (JEL) kódok: D74, G21, O33, N74

Kulcsszavak: bizalom, etika, bankok, FinTech, mesterséges intelligencia, Regulatory Sandbox

\footnotetext{
* A jelen kiadványban megjelenő írások a szerzők nézeteit tartalmazzák, ami nem feltétlenül egyezik a Magyar Nemzeti Bank hivatalos álláspontjával.

Kerényi Ádám a Magyar Tudományos Akadémia Világgazdasági Intézetének kutatója.

E-mail: kerenyi.adam@krtk.mta.hu

Müller János közgazdász, a Magyar Bankszövetség vezetö tanácsadója. E-mail: mullerj1@t-online.hu

Köszönjük a két anonim lektornak az építő megjegyzéseiket és javaslataikat.

A magyar nyelvű kézirat első változata 2019. május 27-én érkezett szerkesztőségünkbe.

DOI: http://doi.org/10.25201/HSZ.18.4.534
} 


\section{Bevezetés}

A bankszektor évszázadok óta bizalmi alapokon múködő ágazat, bőséges tapasztalattal rendelkezik arra vonatkozólag, hogyan kell felépíteni és megtartani az ügyfelek és a piac bizalmát, ugyanakkor mindez milyen gyorsan elveszíthető. A bizalom és a biztonság ismételt felépítése és visszaszerzése - a gazdasági válságok tanulságait ismerve - lassú, nehéz folyamat. Mindebben természetesen szerepet játszanak a banki múködés külső feltételei: az intézményi háttér, a szabályozás és a felügyelet, valamint a gazdaságpolitikai környezet, a monetáris és fiskális politika összhangja. Probléma, recesszió, válság, esetleg bankcsőd esetén a szabályozók azonnal lépnek, a „vétkeseket vagy búnösöket”, azaz a bankokat azonosítják, céljuk a szektor-szintü veszteségek csökkentése, majd a helyreállítás és a bizalom újraépítésének segítése (Kerényi - Molnár 2017 és Kerényi - Müller 2019).

A bankszektornak mint bizalmi ágazatnak, törvényileg is szabályozott múködési alapelve a banktitok megtartása, az ügyféladatok szigorú megőrzése. További elvárás a hagyományos bankok esetében az etikai normák és követelmények alkalmazása, érvényesülésük biztosítása. A gazdaság normális működése idején a bizalom, a megbízhatóság, az etika, az üzleti jó hírnév érték, a sikeres profitabilitás eszköze. Kérdés, hogy mindezek az elvárások, szakmai követelmények hogyan változnak, alakulnak át egy forradalminak minősített fejlődési folyamatban, amikor a digitális világ elérte a pénzügyi szolgáltatásokat, kikényszeríti a hagyományos bankok üzleti modelljének átalakítását, a pénzügyi piacokra új szereplők és versenytársak lépnek, és ennek következtében változik vagy változnia kellene a szabályozás és felügyelet rendjének. Ebben az összefüggésben vizsgáljuk, hogyan alakulnak kényszerűen a fenti tényezők a hagyományos bankokban és a FinTech- vagy BigTech-vállalkozásokban, hogyan változik a bank bizalmi viszonya ügyfelével. Egyenlő versenyfeltételek biztosítottak-e a hagyományos bankok és a piacra lépő új, digitális szolgáltatók között? Hasonló kérdések merülhetnek fel a szabályozás oldaláról is. A bankok minden tevékenysége, ide értve a digitális szolgáltatásokat is, szabályozott és ellenőrizhető.

„Hogyan lehet felépíteni a bizalmat a digitális korban?” - tette fel a kérdést Roland Busch, a Siemens vezetője. „A digitális technológiák megváltoztatják életünket és gazdaságunkat. A mesterséges intelligencia, a nagy adatelemzés, a blockchain és a felhő-technológiák számtalan módon javítják világunkat, de új sebezhetőséget is magukkal hoznak. A digitalizáció és a globalizáció megváltoztatja a paradigmákat és új lehetőségeket teremt" (Busch 2018:1).

Azonosíthatók-e a határokon átnyúló digitális pénzügyi szolgáltatások a szabályozás szempontjából? Melyik joghatóság nyújt bizalmi hátteret: a FinTech-cég bejegyzési országa, vagy a szolgáltatás igénybevételének helye? Mire alapozzák a fogyasztók bizalmukat a FinTech-cégek szolgáltatásaival kapcsolatban? Átalakulnak-e a hagyományos bankok etikai kódexei a digitális verseny hatására? Lehet-e beszélni 
FinTech-bizalomról és -etikáról? Az alábbiakban e folyamatok alakulását nyomon követve adunk helyzetképet a jelenleg ismert állapotról. Vizsgálatunk során szükségszerú, hogy először a bankszektor és a bizalom, valamint az etikus magatartás viszonyát tekintsük át, majd azt elemezzük, hogy ez a viszony hogyan alakul a FinTech világában.

\section{Bizalom, megbízhatóság és etika a hagyományos bankok világában}

A modern társadalmak életében van néhány olyan tevékenység ${ }^{1}$, szolgáltatás, amely jelentős mértékben bizalomra és titoktartásra épül. A titoktartás teljesülése nélkül a bankrendszer nem múködhetne, annak tudatosult léte alapozza meg a bizalmat. A bankrendszer múködésének évszázadok során kialakultak a meghatározó, az alaptevékenység jellegéből fakadó követelményei: a bizalom, biztonság, megbízhatóság és az ügyfelekkel szemben tanúsított etikus magatartás.

Ezek együttese alapozza meg a bank jó üzleti hírnevét, reputációját. Adott bank integritásával és megbízhatóságával szembeni bizalom akkor alakítható ki, ha döntéshozatalában és tevékenysége során a törvények és részletes szabályok mellett érvényesülnek az etikai és erkölcsi normák. A bizalom, az azt erősítő etikus magatartás és a jó üzleti hírnév a bankok sikeres múködésének fontos feltétele, vagyis ezek megléte értéket képvisel.

A bizalom alapvetően emberi kategória, tapasztalások, hosszabb problémamentes együttmúködés vagy nehezebb feladatok közös megoldásának élménye alapján alakul ki. Fontos előfeltétele a pénzügyi, vagyoni titkok megőrzése. A bizalom kialakulásának vannak a pénzintézetektől független külső feltételei, úgymint a jogszabályi környezet, a pénzintézeti törvények, a szabályozás és felügyeleti rendszer, de ide sorolható a pénzügyi tudatosság szintje is egy adott országban. Az úgynevezett belső feltételek közé tartozik a bank irányítási rendszere, a döntéshozatal, kockázatkezelési szabályok és eljárási rendek. A külső és belső szabályok betartását egészíti ki a bizalomépítés témánk szempontjából kritikusan fontos eleme, a banki alkalmazottak etikus magatartása, integritása.

A bizalomért meg kell dolgozni, ezért az csak hosszabb folyamat eredményeként alakul ki. A megszerzett bizalom megteremti a megbízhatóság remélt vélelmét. Ezek értéke akkor igazolódik be, amikor valamilyen vétség, hiba vagy negatív külső körülmények - például recesszió vagy válság - miatt megroppan egy bank, vagy a bankrendszer iránti bizalom. Bár felépítése ugyan hosszú időt vesz igénybe, de egy

\footnotetext{
${ }^{1}$ Megemlíthetjük az orvosokat, ügyvédeket, vagy az egyházak hitéleti szereplőit. Az emberek mindegyik esetben érzékeny, értékes javaikat, gondjaikat, érzelmeiket osztják meg a felkeresettel. Van-e nagyobb kincs, mint az egészség? Kell-e nagyobb bizalom, mint amikor valaki reméli, hogy orvosa meggyógyítja? Lelkipásztorától együttérzést és lelki megnyugvást vár a hívő. A bankok pedig ígérik, hogy szorgos megtakarításaik, a család tartalékai felett őrködnek, terveik megvalósításához hitelt nyújtanak. Ezek azok a területek, ahol nem csak létezik, hanem elvárt és kötelező a titok fogalma.
} 
perc alatt romba dőlhet. A bizalom elvesztésének előfordulhatnak drámai fordulatai, amikor az pánikot vált ki, az ügyfelek tömegesen menekülnek bankjukból vagy a bankoktól. A bizalom megroppanása ugyanis - számos banktörténeti példa igazolja - ragályos és fertőző, terjedése rendkívül gyors ${ }^{2}$. A bizalom és a hitelesség néhány építő eleme a múltbeli teljesítmény, kiváló referencia, stabilitás, eredményesség, megbízható és ellenőrizhető tulajdonosi struktúra, kiszámíthatóság, a szolgáltatások és ügyfélkapcsolatok minősége és lehetőleg hosszabb, folyamatos ügyfélkapcsolatok.

Ahhoz, hogy az elvárt bizalom kialakuljon, az adott kapcsolatnak ki kell állnia a bizalmatlanság próbáját. A kapcsolat kezdetekor mindkét félben van bizalmatlanság és gyanakvás. A bank például egy hitelkérelem esetén hivatalból és már meglévő betéteseinek védelme érdekében bizalmatlan, azaz kockázatelemzést végez, amihez leendő ügyfelétől, ügyfeléről számos adatot igyekszik begyűjteni. Az ügyfél pedig arról akar meggyőződni, vajon pénzének, esetleg vagyonának kezelését megbízható intézményre bízza-e.

A bizalom kialakulása tehát olyan folyamat eredménye, amikor a bizalmatlanság, gyanakvás és a megbízhatóság egyensúlyba kerül. A bankok számára akkor lehet sikeres az üzleti tevékenység - egyéb fontos tényezők mellett -, ha ez az egyensúly minél hosszabb ideig fennmarad. Egy jól múködő bankban a széles értelemben vett jogszabályok betartása és az etikai követelményrendszer egymás mellett, egymást erősítve múködik. A sorrend is fontos, mert elsőbbséget élvez a szigorú törvényi és belső szabályozás, amely átfogja a banki tevékenység minden folyamatát, amihez szervesen kapcsolódik az etikai normák rendszere. Ugyanakkor a jogi keretek és a szabályozás nem terjedhet ki mindig és mindenkor a banki tevékenység részleteire. Ezt egészíti ki a bankokban alkalmazott etikai, erkölcsi normák követelménye és a szakmai integritás igénye. A banki etikának könyvtárnyi irodalma van, jelen keretek között csak utalunk a banki etikai normák általánosan elfogadott alapelveire. A szakirodalomban a hagyományos bankok etikai magatartásának követelményei tartalmaznak néhány örökérvényű és elmaradhatatlan követelményt. Ilyen például az átláthatóság, becsületesség, tisztesség, a felelősség, a kiszámíthatóság és az ügyfelek tisztelete (Villa 2015:83)

Az etika ${ }^{3}$ és a morál az általános felfogás szerint inkább alapvető értékrendekre, normákra vonatkozik. Mindkettő belső emberi értékrendet takar, ami segít eligazodni a jó és a rossz, a helyes és helytelen, az igazságosság és igazságtalanság kérdéseiben. Ezért általános az a felfogás, hogy az etika olyan kifejezés, amely kimondottan, vagy kimondatlanul, tudat alatt is létező erkölcsi normáinkat takarja, amelyek

\footnotetext{
${ }^{2}$ Ezért is ellenőrzi például az Európai Központi Bank a rendszerszintű kockázatot képviselő bankokat.

${ }^{3}$ Az etika szó görög eredetű, eredeti jelentése az „éthos”, ami szokást, hagyományt, viselkedési formát jelent. Az etika szinonimájaként gyakran használják az erkölcs, morál szót, amely a latin „mores”-ből ered. Ennek jelentése helyes cselekedet, kifogástalan magatartás. A mindennapi szóhasználatban az erkölcsöt, morált gyakrabban használják.
} 
helyzetmegítélésünk, cselekvésünk és döntéseink mögött állandóan meghúzódnak4 A belső értékrendnek, az egyén etikai normáinak kialakulásában szerepet játszik a kulturális és vallási hagyomány, a családi környezet és neveltetés, a törvények és jogszabályok által kialakított társadalmi környezet, és végül, de nem utolsó sorban az adott hivatás vagy munkahely követelményrendszere. Esetünkben a hivatás és tevékenység tárgya a banki szolgáltatások nyújtása, a pénzügyi közvetítő rendszer kifogástalan múködtetése.

Az elmondottakból érzékelhető, hogy ezek a normák ${ }^{5}$ a társadalom és a civilizáció fejlődésével változnak, változhatnak, de vannak olyan pillérei, amelyek évezredek óta állandók, vagyis az etikai normáknak kifinomult követelményrendszere alakult ki az évtizedek, sőt évszázadok során. Első tétele az érvényes és hatályos szabályok betartása. Olyan szolgáltatások és termékek kínálata, amelyek megfelelnek a vonatkozó elő́rásoknak, az érintett ügyfelek pedig a termékről pontos, átlátható információt kapnak. Ezt a követelményt erősíti az a régi mondás, mely szerint ahol véget ér a törvény, ott kezdődik a tisztesség. A banktitok, az adatvédelem és a titoktartás minden banki etikai kódexben kiemelt jelentőséget kap. A banketika ugyancsak fontos aranyszabálya a lehető legteljesebb objektivitásra való törekvés, mindenfajta befolyásolás, részrehajlás kerülése. Az időtényező szerepe is kiemelt. Ezt a szempontot úgy lehet röviden bemutatni, hogy a bankszakmában minden sürgős és semmi sem lehet sürgető. Rohanó világunkban, amikor üzleti döntések és információk elektronikus, digitális úton percek alatt továbbíthatók, a gyorsuló időtényező téves kockázatfelmérést és hibás döntést eredményezhet.

Visszatekintve gazdasági ciklusokat, válságokat megélt bankok történetére, azt látjuk, hogy a bizalom és etika kérdései hangsúlyosan egy-egy mélyebb recesszió vagy válságperiódus után kerülnek előtérbe. Úgy is mondhatjuk, hogy a bankokkal szembeni bizalom és az etikai elvárások szoros kapcsolatban, korrelációban vannak a gazdasági ciklusokkal. Ezek a kérdések akkor kerülnek előtérbe és válnak vizsgálat tárgyává, amikor egy gazdaság és annak bankrendszere túljutott a válság mélypontján, eredményes volt a szanálás és helyreállítás folyamata. Ekkor a bankok esetében napirendre kerül a bizalom helyreállítása, megerősítése és ennek érdekében az etikai normák megkövetelése. A banki etikai normák változását egy-egy gazdasági ciklust követően jól érzékelteti Koslowski helyzetmegítélése: „a pénzügyi piacok válsága váratlanul reflektorfénybe állította a pénzügyi piacok és pénzügyi intézmények etikai kérdéseit, ami széleskörű érdeklődést váltott ki. [...] A pénzügyi válság nemcsak a gazdasági rendszer válsága, hanem a pénzügyi közvetítők válsága

${ }^{4} \mathrm{Ez}$ az utalás azért lényeges, mert később ezeknek a viselkedési normáknak az érvényesülését keressük a FinTech világában.

${ }^{5}$ Gondoljunk csak a Bibliára, ahol az Ószövetségben a Tízparancsolat volt a törvény, annak például egyik örökérvényű szabálya a „Ne lopj!”. Az idők folyamán ennek a törvényi tételnek a tartalma is sokat változott. Ma már nem csak arról szól, hogy valaki egy tárgyat elvesz, lopás például az adócsalás is, de gyakran helytelen banki szerződéseket is hajlamosak az ügyfelek lopásnak minősíteni. 
is, akiknek a viselkedése azzal fenyegetett, hogy a pénzügyi ágazatot egy határok nélküli öngazdagodás irányába viszik el" (Koslowski 2011:3).

A 2008-as nemzetközi pénzügyi válság kitörése utáni időszakban azt láttuk, hogy az Európai Unióban a bankszektor biztonságos múködését erősítő egész szabályozási arzenál és intézményi architektúra alakult ki. Elég, ha megemlítjük az Európai Központi Bank (European Central Bank, ECB) kibővített és megerősített hatásköreit, vagy utalunk az Európai Felügyeleti Hatóságok (European Supervisory Authorities, ESA), Európai Bankhatóság (European Banking Authority, EBA), az Európai Biztosításés Foglalkoztatóinyugdíj-hatóság (European Insurance and Occupational Pensions Authority, EIOPA), az Európai Értékpapír-piaci Felügyeleti Hatóság (European Securities and Markets Authority, ESMA), az Egységes Európai Felügyeleti Mechanizmus (European Single Supervisory Mechanism), az Európai Szanálási és Helyreállítási Alap és Mechanizmus (European Funds and Mechanisms for Bank Resolution and Recovery) és az Európai Rendszerkockázati Testület (European Systemic Risk Board, ESRB) múködésére. Mindeközben folyamatosan épült a Monetáris Unió, a Bankunió és a Tőkepiaci Unió. Nemzeti hatáskörökben is hasonló, a bankok biztonságos működését garantáló szabályok és intézkedések kerültek bevezetésre. A magyar gyakorlat is összhangban volt az előbb említett folyamatokkal és célkitǔzésekkel. A 2009 és 2015 január közötti időszakban a bankszektorra vonatkozóan közel száz törvény és jogszabály jelent meg (29 törvény, 21 kormányrendelet és nagyszámú miniszteri és Magyar Nemzeti Bank (MNB) elnöki rendelet), ezenfelül át kellett venni a magyar jogrendbe a ránk is érvényes uniós direktívákat.

Ez a válság utáni időszakokra jellemző (túl)szabályozás szükséges volt a bankszektor stabilitásának helyreállításához és egyben erősítette az európai és ezen belül a magyar bankszektorral szembeni bizalmat. Folyamatosan ellenőrizték például a tőkekövetelmények betartását, vagy a rendszerszintű kockázatot képviselő bankok helyzetét. Az állami segítséggel szanált bankok nem vállalhattak túlzott kockázatokat hordozó hitelmúveleteket. Újraindult a bankközi finanszírozás és a bankközi verseny. Azt gondolhatnánk, hogy mindez elégséges volt a bizalom helyreállításához. Nem így volt. Szinte szabályszerűen napirendre kerültek az etikai és erkölcsi kérdések. Ismét magyar példát idézünk: már 2010 elején megjelent a bankszektorra vonatkozó Magatartási Kódex, amelynek elsődleges feladata az volt, hogy magatartási, etikai oldalról lefedje azokat a részterületeket, melyeket a jogszabályok akkor még nem voltak képesek kezelni. Ezt a Kódexet 2015-ben módosították, mivel időközben az előző változat több tétele beépült a jogszabályi keretekbe. A Kódex megköveteli, hogy a bankok önkéntesen érvényesítsék a következő alapelveket: transzparencia, szabályelvűség és az információs szimmetria elve.

„A Kódexet aláíró hitelezők [...] kizárólag abban érdekeltek, hogy a tisztességes verseny és a korrekt üzletmenet eszközeivel támogassák a lakossági ügyfélkörük és ezen keresztül a magyar gazdaság fejlődését. Meggyőződésük, hogy jelen önsza- 
bályozásuk - a hatályos magyar jogszabályok rendelkezéseit nem helyettesitve, hanem azokat erkölcsi normák figyelembevételével kiegészítve - tovább erősitik az elégedett fogyasztókért folytatott piaci versenyt, a hitelezési szolgáltatások minőségét és eredményességét a lakosság körében" (Magyar Bankszövetség 2015:1).

A fenti idézetekben vizsgálatunk tárgyának legtöbb kulcsszava megtalálható: tisztességes magatartás, szabályok betartása, önszabályozás, erkölcsi normák, közérthetőség, tisztességes piaci verseny. Ki kell azonban emelni a kódexben meghatározott három elvet: a transzparencia, a szabályszerúség és a szimmetria elvét. Erre is tekintettel a kódexet aláíró bankok a tisztességtelen kereskedelmi gyakorlat tilalmáról szóló 2008. évi XLVII. törvény alapján vállaltak kötelezettséget, ami azért különös és egyedi, mert ennek alapján a Kódex jogérvényű kötelezettséget jelentett az aláíró bankok számára. Az, hogy egy magatartási, etikai kódex jogérvénnyel bír, egyértelmúen a válság hatásának tudható be. Ezzel egy időben, ennek megfelelően a kereskedelmi bankok átdolgozták saját etikai kódexüket, belső magatartási normáikat. E folyamat részeként a Magyar Bankszövetség is korszerüsítette etikai kódexét és Etikai Bizottságának működési rendjét.

A bizalomerősítő intézkedések része volt a betétbiztosítási rendszer erősítése, a biztosított keretösszeg emelése. Ebben követtük az Európai Unió ide vonatkozó, számunkra is kötelező érvényű direktíváját, megemelve a betétbiztosítási keretösszeget, ami összhangban volt azzal az Uniós céllal, hogy a Bankunió fejlesztése során az egységes felügyeleti mechanizmus és az egységes szanálási mechanizmus mellett az Európai Betétbiztosítási Rendszer (EDIS) is megvalósuljon.

A 2010-es évek közepére sikerült helyreállítani a bankszektor normális múködését, ami áldozatok nélkül nem valósulhatott meg. Minden országban hathatós volt az állami beavatkozás, bekövetkezett egy szigorú túlszabályozás és lényegesen módosult a bankok üzleti modellje, szervezete, az irányítás, menedzsment és a kockázatkezelés rendszere. Mindezzel párhuzamosan széles körben alkalmazták az etikai és magatartási normákat. Ebben az új „,békeidőben” került előtérbe a banki etikai normák újrafogalmazása, a bankokkal szembeni bizalom építkezési folyamata. Két kérdésnek azonban van jogosultsága - egyrészt: kialakulhat-e ismét a 2008 előttihez hasonló helyzet a bankszektorban, amit a válság miatt nehéz helyzetbe került Citibank vezérigazgatója, Chuck Prince úgy indokolt és jellemzett, hogy „amíg szól a zene, táncolni kell”? („As long as the music is playing, you've got to get up and dance.”). Másrészt hogyan alakulnak és változnak az etikai és bizalmi követelmények a FinTech világában? 


\title{
3. Bizalom, megbízhatóság és etika a digitális pénzügyi világban? Harmónia és diszharmónia
}

\begin{abstract}
A 2010-es évek közepére tehát a bankszektorral szembeni általános bizalom jelentős mértékben helyreállt. Ebben az időszakban banktörténeti szempontból is számos új elem, változás, kihívás jelent meg a pénzügyi közvetítő rendszerben. A bankok alkalmazkodtak a válság hatására szigorított, a tevékenység részleteire is kiterjedő nemzetközi és nemzeti szabályozáshoz és felügyeleti előírásokhoz. Ahol szükséges volt, ott befejeződtek a szanálások, a bankok megfeleltek az új tőkekövetelményeknek. Megindultak a válság miatt elmaradt számítástechnikai és egyéb fejlesztések. A gazdasági növekedés hatására gyorsuló ütemben nőtt a vállalati és lakossági hitelezés. A kedvezőre fordult helyzetben ismét elindult és élesedett a bankközi verseny. Hamarosan nyilvánvalóvá vált, hogy a bankok múködési környezete jelentősen megváltozott a válság előtti időszakhoz képest. Az új helyzet - hasonlattal élve - úgy jellemezhető, hogy bár a hangszerek és a zenekar tagjainak egy része, jóllehet a régi, de már új zenét kell szolgáltatni, mert megváltozott a hangverseny környezete és a hallgatók igénye is.
\end{abstract}

Ebben a gazdasági békeidőben a bankszektort és az egész pénzügyi közvetítő rendszert elérte a negyedik ipari forradalom részének tekintett digitalizáció, amelynek számos eleme már az ezredforduló idején érzékelhető volt, de robbanásszerű hatása a pénzügyi válságot követően jelent meg. Ezek a „forradalmi” változások új követelményeket támasztanak a pénzügyi szolgáltatásokkal és szolgáltatókkal szemben a bizalom, megbízhatóság és etika területein. Elemzésünk központi témája szempontjából - ismét hasonlattal élve - egy olyan körforgalomhoz értünk, amelynek középpontjában a pénzügyi közvetítő rendszer áll, de mind oda és mind abból kifelé többirányú út vezet. Ezzel az ábrával több következtetésünket szeretnénk megerősíteni, illetve alátámasztani. Mindenekelőtt azt, hogy a digitális pénzügyi szolgáltatások és az azokat nyújtó szolgáltatók világának központjában is a pénzügyi közvetítő rendszer áll. Más szavakkal a hagyományos bankok által múködtetett pénzügyi közvetítő rendszer lehetőségeit használják ki a FinTech- és a BigTech-cégek. A körforgalom második köre azt érzékelteti, hogy a FinTech típusú cégek a pénzügyi szolgáltatások mellett ma már egyre nagyobb mértékben végeznek betéti múveleteket és hitelnyújtást is. A körforgalom külső kerete arra mutat rá, hogy ezt az egész folyamatot körbeveszi a nemzetközi és nemzeti szabályozás és felügyelet igénye. Ezt képviselik a megjelölt nemzetközi és nemzeti szabályozó és felügyeleti hatóságok, illetve az általuk igénybe vett és alapított regulatory sandboxok ${ }^{6}$ és innovation hubok. A jelen helyzetben azonban ez a törekvés döntő többségében az 1. ábra alapját képező bizalom, etika, morál és magatartás most alakuló normáira támaszkodik.

\footnotetext{
${ }^{6}$ Az MNB által használt fogalom: Innovációs Pénzügyi Tesztkörnyezet, IPT (Forrás: https://www.mnb.hu/ innovation-hub/regulatory-sandbox és Fáykiss et al. 2018).
} 


\section{1. ábra}

\section{FinTech-ek és hagyományos bankok szolgáltatásainak körforgalma}

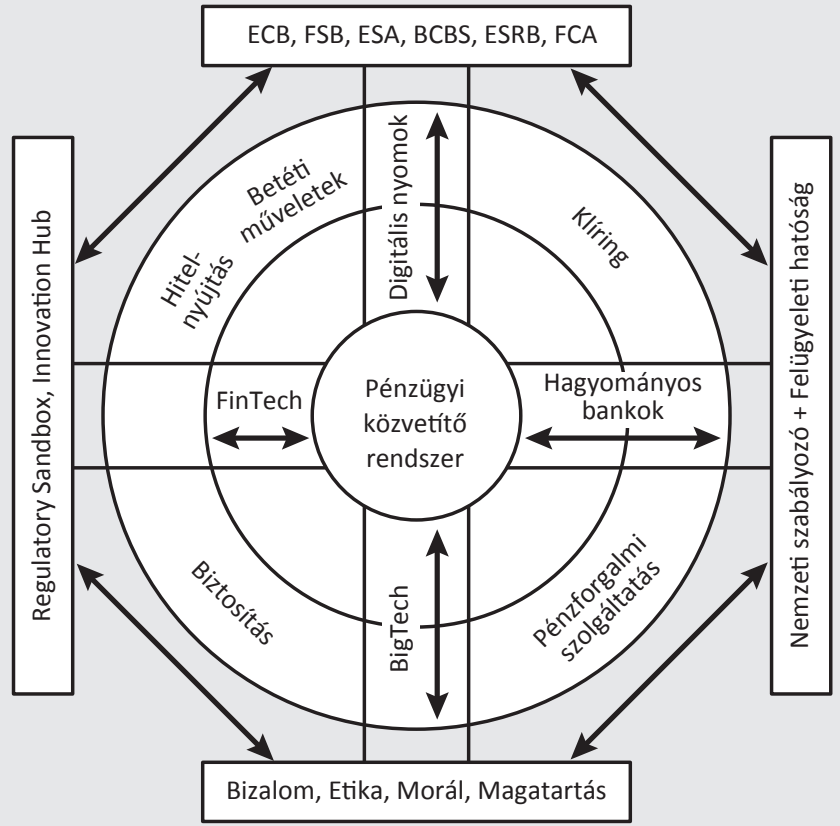

A körforgalommal jellemzett útelágazásnál több oldalról érkeztek és jelentek meg az új szereplők. Megjelenésüket a digitális világ beköszönte hozta, kezdetben még elsőbbséget adva a pénzügyi piac hagyományos szereplőinek. A FinTech-startupok kihasználták, hogy a hagyományos bankok a válság utáni kilábalás korszakában lassabban tudták internetes, digitális szolgáltatásaikat bevezetni. Az első időszakban a berobbanó szolgáltatókat az jellemezte, hogy digitális, innovációs fejlesztésekre alapozva, kis tőkeigénnyel alapítsanak gyorsan megtérülő, jól jövedelmező vállalkozásokat, kihasználva a piaci rést, amit a gyors és olcsó pénzforgalmi szolgáltatások iránti kereslet támogatott. A digitális fejlődést az Európai Unió és tagállamai is globális versenyképességi kérdésnek minősítették, a FinTech-startupok több szinten fejlesztésük és piacra lépésük általános támogatását élvezték. Ugyanakkor a hagyományos bankok csak a rájuk vonatkozó feszes szabályok betartása mellett jelenhettek meg ilyen szolgáltatásokkal A FinTech-cégeket a szabályozók viszont a bankszektoron kívül állóknak tekintették. Ennek egyik oka az volt, hogy kezdetben a FinTech fogalmának nem volt általánosan elfogadott, a szabályozás számára alkalmas definíciója a szakirodalomban. Még mindig általánosan a Bázeli Bankfelügyeleti Bizottság (Basel Committee on Banking Supervision, BCBS) Pénzügyi Stabilitási Tanácsának (Financial Stability Board, FSB) meghatározását használják, amelynek értel- 
mében a FinTech jelentése „technológiavezérelt pénzügyi innováció, amely olyan új üzleti modelleket, alkalmazásokat, folyamatokat vagy termékeket eredményezhet, amelyek jelentős hatással lehetnek a pénzügyi piacokra és intézményekre, valamint a pénzügyi szolgáltatásokra". Ez a tág meghatározás a BCBS megítélése szerint pragmatikusan használható a FinTech fejlődésének jelenlegi változékonysága mellett is.

Ez a kezdeti általános támogatás, valamint a megengedő és tág definíció természetesen komoly következményekkel járt, mivel a meghatározás nem azonosítja egyértelműen a FinTech-szolgáltatások tartalmát és körét, megnehezíti a jogszabályi keretek és a felügyeleti ellenőrzések határainak kijelölését, valamint a hagyományos bankok és a FinTech-vállalatok közötti verseny egyenlő feltételeinek biztosítását.

Ebben a kezdeti környezetben a bizalom kérdése érdemben nem merült fel sem a szabályozók, sem az ügyfelek részéről. Nem jelentkezett lényeges bizalmi kérdőjel, esetenként csak a bankok tiltakoztak az egyenlőtlen versenyfeltételek miatt. Mi hozta létre, vagy okozta ezt a bizalmat meg nem kérdőjelező helyzetet?

A FinTech-vállalkozások a kezdetekben egy kisebb „niche” ügyfélszegmens elérése esetén is sikeresek lehettek, a később megjelenő BigTech-vállalatok pedig a nem pénzügyi szolgáltatásaik kiegészítéseként ajánlották - többek között - hiteleiket. Ebben a megváltozott környezetben a bizalom építését alapvetően befolyásolta, hogy gyorsuló ütemben és lényegesen megváltozott az ügyfélkapcsolatok természete, jellege. A hagyományos bankok esetében kapcsolataikat vállalati vagy lakossági ügyfeleikkel az tette egyedivé, hogy a hangsúlyt a stabil, hosszú távú kapcsolatokra helyezik, vagyis az ügyfél - bank viszony kapcsolatorientált (kiemelés a szerzőktől), szemben a FinTech-szolgáltatókkal, ahol a kapcsolat többnyire egyszeri, tranzakcióalapú. Utóbbiak esetében - legyen szó mobil fizetésről, elektronikus banki ügyintézésről, internetes, hitellel egybekötött vásárlásokról - közös vonás, hogy a szolgáltatás igénybevétele gyors, kényelmes, hatékony és olcsó. Ugyanakkor a digitális szolgáltatás igénybevétele rövid ideig tart, eseti az igénybevétel helye és eszköze, nincs tartós és főleg nincs emberi vagy intézményi kapcsolat. Ezt a minőségi különbségtételt a harmincegy ország banki közösségét összefogó Európai Bankföderáció (European Banking Federation, EBF) fogalmazta meg a bankok jövőbeni, a gazdaság fenntartható finanszírozását igénylő egyenlő versenyfeltételek kapcsán (EBF 2018:3). A BigTech-szolgáltatók megjelenése ebben az összefüggésben kétarcú, mert többszöri vagy tartósabb ügyfélkapcsolataik kereskedelmi jellegűek, és erre építve nyújtanak eseti pénzügyi szolgáltatásokat.

A digitális korszak komoly kihívás elé állítja a hagyományos bankokat, de az ügyfeleket is. Az új, vagy megújítandó bizalmi viszony kialakításához bizonyítaniuk kellett, hogy a legutóbbi globális pénzügyi válság negatív hatásait feldolgozták, stabil, fenntartható és jövedelmező a tevékenységük, ügyfeleik számára versenyképes és megbízható szolgáltatásokat nyújtanak. Bizonyítaniuk kellett továbbá azt is, 
hogy belátható időn belül minden olyan szolgáltatást nyújtani fognak, amelyeket a FinTech-cégek ajánlanak. El kell (kellene) érniük, hogy ügyfeleik belássák: előnyük származik egy tartós banki kapcsolatból.

Már említettük, hogy a bizalom és bizalmatlanság egyensúlyából alakulhat ki egy olyan helyzet, amire építeni lehet. „Ha a digitális gazdaság lételemét az adatok képezik, akkor a szíve a digitális bizalom - az emberekbe, folyamatokba és technológiákba vetett bizalom szintje egy biztonságos digitális világ kiépítéséhez. A vállalatoknak, a szabályozóknak és a fogyasztóknak új mechanizmusokra van szükségük a bizalom kiépitéséhez, mivel az üzleti, kockázatvállalási és megfelelöségi kihívásokkal kell megküzdeniük" (Fleming 2018:1). Elérkeztünk egy lényeges kérdéshez, a bizalmi többlet és a bizalmi deficit problémájához a hagyományos bankok és a FinTech-szolgáltatók viszonyában. Tapasztalati tény, hogy a FinTech-megoldásokat előnyben részesítő, fiatalabb generáció fejlett digitális, internet-használati készségekkel rendelkezik, a gyors és olcsó fizetési megoldásokban hisz, ugyanakkor pénzügyi tudatosságuk nem mindig van összhangban ezzel a képességükkel. Ebben az aránytalan helyzetben és ebben az ügyfélszegmensben a hagyományos bankok egyensúlyteremtése, bizalomszerzési és bizalomépítési feladata lényegesen megváltozik.

\section{Hol tart a digitális pénzügyi architektúra építése?}

A forradalmi változások közös jellemzője, hogy rendkívül gyorsak, és nemegyszer a kialakult hagyományos rendet felforgatók (diszruptív). A központi bankok, szabályozó hatóságok és felügyeletek igyekeznek szorosan nyomon követni a gyorsan változó digitális fejlődést. Miközben a FinTech-megközelítésük alapvetően támogató (pl. ún. Regulatory sandboxok, FinTech Hubok), megjelentek az első figyelmeztető jelek. Egyre több hatóság és tanulmány javasolta az ilyen típusú szolgáltatások szabályozását, etikai követelmények felállítását és a fogyasztói bizalom, biztonság erősítését.

2016-2017-től gyorsultak fel azok az események, amelyek jelezték, hogy a szabályozás nélküli vagy laza szabályozású FinTech-folyamatok kockázatokat jelenthetnek, ezért sürgették a szabályozást és egyben a nemzetközi együttmúködést. Hangsúlyozottan megjelent ugyan az azonos szolgáltatások, azonos szabályozás és az egyenlő versenyfeltételek elvének követelménye, azonban ezen a téren nem történt jelentős előrelépés.

A legmagasabb szintű nemzetközi szabályozási szervezet, a Pénzügyi Stabilitási Tanács 2016-ban kezdte mélyebben vizsgálni a FinTech-jelenség szabályozási és felügyeleti kérdéseit, 2017-ben pedig már lehetséges pénzügyi stabilitási kérdéseket vetett fel, amikor jelentésük szerint ezek a potenciális kockázatok magukba foglalják az intézményspecifikus mikropénzügyi kockázatokat, amelyek rendszerszin- 
tü, makropénzügyi kockázattá is alakulhatnak, többek között az adatok nagyfokú összekapcsolódása miatt. E következtetések alapján az FSB szorosan figyelemmel kíséri a FinTech-folyamatok következtében fellépő stabilitási következményeket.

Az FSB 2019. év eleji jelentése már megállapítja, hogy a FinTech-szolgáltatások hatással vannak és lehetnek a piaci struktúrára és a pénzügyi stabilitásra. Elemzésében a FinTech-ek piaci jelenlétének három típusát vizsgálta (FSB 2019):

1. A pénzügyi intézmények partnerei (vagy átvehetik őket), lehetővé téve a pénzügyi intézmények számára, hogy javítsák szolgáltatási szintjüket vagy hatékonyságukat.

2. Olyan szolgáltatást nyújthatnak, amely kiegészíti a meglévő pénzügyi intézmények által nyújtott szolgáltatásokat. Ez javíthatja a meglévő szolgáltatás vonzerejét, pl. a "front-end” kifizetésekkel, amelyek használják a meglévő hálózatokat és bővítik, gyorsítják a tranzakciós folyamatokat. Noha ezek a szolgáltatások kiegészíthetik a pénzügyi intézmény által kínált szolgáltatásokat, az intézmény hagyományos ügyfélszolgálatának helyettesítésével vagy gyengítésével káros hatással lehetnek a pénzügyi intézményre.

3. Közvetlenül versenyezhetnek a meglévő pénzügyi intézményekkel, csökkentve az érintett szegmensek árrését, és csökkenthetik a pénzügyi intézményeknek a termékek keresztfinanszírozására való képességét.

Ezen három terület beható elemzése alapján az FSB megállapítja, hogy a feltárt kockázatok három okból is súlyosbodhatnak: a) Az elmúlt években bevezetett új technológiák tömege és a nyílt banki szolgáltatások bővülése gyorsan megváltoztathatja a verseny dinamikáját. b) Az üzleti modellek változása gyorsabban bekövetkezhet, mint a múltban, mivel a BigTech-cégek aktívan és sikeresen hatolnak be a hagyományos pénzügyi szolgáltatások területére. c) Az új szolgáltatók és a hagyományos bankok technológiai fókuszpontja - különösen, amikor szorosan integrálódnak a vállalatok működésébe - a múködési kockázatok új dimenzióját nyithatják meg.

Az FSB felhívja a szabályozók figyelmét az új típusú kockázatokra a pénzügyi stabilitás esetleg bekövetkező sérelmére. „Ezekből a fejleményekből származó lehetséges makroszintü pénzügyi kockázatok visszavezethetök a verseny hatásaira és az üzleti, jövedelmezőségi modellek megbontására, így annak megakadályozására, hogy a tőkét a megszerzett jövedelemből halmozzák fel. Ez nagyrészt annak a következménye, hogy a FinTech-cégek aktívan versenyeznek a hagyományos bankokkal, illetve tevékenységük növeli az ügyfelek mobilitását. Ez végső soron a bankok hitelezési elöírásainak nem megfelelö lazulásához vezethet, miközben más pénzügyi intézmények nagyobb kockázatot vállalhatnak” (FSB 2019:16). Az FSB megállapítja, hogy „ezen túlmenően a BigTech-cégek különböző ingyenes szolgáltatásokat tudnak nyújtani, mert képesek az elért adatokat más üzleti céljaikra felhasználni. Az ügyfelek a szolgáltatásuk igénybevételéért cserébe személyes adataikkal fizetnek" (FSB 2019:19). 
A lehetséges kockázatok csökkentése vagy megszüntetése természetesen közvetlen hatással lehet a pénzügyi szolgáltatókkal szemben kialakuló vagy meggyengülő bizalomra. Ezzel összefüggésben az FSB a szabályozás szükségessége mellett nyomatékosan felhívja a figyelmet, hogy már az induláskor meg kell határozni a FinTech-szolgáltatók tevékenységének engedélyezési feltételeit.

A szabályozás és engedélyezés kérdéskörében utalunk arra, hogy az Európai Központi Bank 2018-ban tette közzé a FinTech-engedélykérelmek értékelésére vonatkozó útmutatót, illetve a FinTech hitelintézeti engedélykérelmek értékelésének útmutatóját (ECB 2018). Eszerint az engedélyezési folyamat során értékelt általános kritériumok közé tartozik, de nem kizárólagosan, a következő négy terület: a) irányítás/governance (az igazgatóság tagjainak és a részvényeseknek az alkalmassága); b) belső szervezet (kockázatkezelés, megfelelési és ellenőrzési keretrendszerek); c) működés rendje; d) tőke, likviditás és fizetőképesség.

A fentiekben leírtak két tanulsággal mindenképpen szolgálnak. Egyrészt az illetékes pénzügyi szervezetek (FSB, ECB) támogatják a FinTech-szolgáltatókat, működésüket fontosnak tartják, ez a napfényes oldal. Másrészt rámutatnak komoly figyelmeztető jelekre, akár a pénzügyi stabilitás, akár a digitális verseny kikényszerített negatív hatásai miatt, ami a FinTech-világ körvonalazódó árnyoldala.

Mint láttuk, az FSB és az ECB is hangsúlyozza a digitális pénzügyi szolgáltatások engedélyezését és szabályozását, valamint az azzal kapcsolatos nemzetközi együttmúködést, de magát a szabályozást, azaz a problémák megoldását kényszerúen továbbra is nemzeti hatáskörbe utalják.

A figyelmeztető jelek szaporodnak, az átfogó szabályozás késésének megértéséhez azonban át kell tekinteni a digitális pénzügyi szolgáltatások elválaszthatatlan eszközét és hátterét, a nagy tömegű adatfelhasználást, az ügyfelek által hátrahagyott adatok igénybevételét, az adatok hasznosítását segítő mesterséges intelligenciát $(\mathrm{Al})$, a gépi adatelemző módszereket (bigdata és $\mathrm{API}^{7}$ ), valamint a robottechnikát. Ugyanis erről az oldalról vetődik a legtöbb árnyék a FinTech-re, ezért itt a legerősebb a bizalom és az etika követelménye. A Hong-Kong-i Egyetem kutatói ezt úgy írták le, hogy „A FinTech-re gyakran úgy tekintenek, mint a pénzügyi szolgáltatások és az információs technológia közelmúltbeli kivételes házasságára" (Arner et al. 2015:3).

A gyors digitális fejlődés mellett ez az összetett képlet teszi nehézzé a szabályozást. A szabályozók ugyanis arra törekszenek, hogy az ajánlott és nyújtott pénzügyi szolgáltatásokat szabályozzák, ugyanakkor ezeknek a szolgáltatásoknak az eszközeit (például nagy adatok, Al) nehéz azonosítani és szabályozni. Ennek egyik jól érzékel-

${ }^{7}$ Application Programming Interface (alkalmazás-programozási felület) 
hető példája, hogy a FinTech-cégek nagy mennyiségű adat felhasználásával nyújtják szolgáltatásaikat. Ezeknek az adatoknak egy részét az ügyfelek önként és tudatosan adják át, más esetekben viszont nem is értik, mihez adják beleegyezésüket, illetve nem is tudják, hogy adataik honnan származnak. Ez utóbbiak nagy hányada az úgynevezett hátrahagyott adat. Ennek természetét egy svéd kutató így jellemzi: „,... nemzetközi szinten vitatott téma, hogy ki a tulajdonosa, birtokosa a digitálisan gyüjtött és felhasznált adatoknak" (Bogusz 2019:1). A hagyományos bankok esetében ez a kérdés egyértelmú volt: az adatoknak csak két tulajdonosa lehetett, az ügyfél és a bank. Ezeket az adatokat szigorúan védte a banktitok. Ennek megléte nélkül nem létezhetett volna bizalom és üzleti kapcsolat bank és ügyfél között. „A digitális hátrahagyott adatokon alapuló üzleti modellek hosszú távú fenntarthatósága megköveteli, hogy a vállalatok mind az adatvédelmi, mind a minöségi szempontokat szem elött tartsák, amikor szolgáltatásaikat fejlesztik. Tekintettel az adatgyüjtés potenciálisan erőszakos jellegére és a lehetséges negatív visszahatás következményeire, a FinTech-cégeknek óvatosnak kell lenniük, amikor szolgáltatásaikat tervezik. A személyes adatok védelmét, azok kezelhetőségét egyértelmü szabályokkal kell rendezni a jelen és jövőbeni FinTech-cégek számára, és megkerülhetetlen, hogy e kérdés morális és etikai vonatkozásait figyelembe vegyék" (Bogusz 2019). Ezt az elvi elvárást támasztja alá az a tény is, hogy a mesterséges intelligenciát a FinTech-szolgáltatók több területen veszik igénybe, így a hitelkérelmek minősítésekor, közvetlen hitelnyújtáskor, a befektetési portfóliók optimalizálásakor, a biztosítási célú eszközök kockázatelemzésekor, vagy a csalás gyanújának és a szabályozási megfelelésnek történő vizsgálatkor.

A nagytömegü, esetenként erőszakosan megszerzett adatok támogatják a FinTech gyors, változatos formákat öltő térnyerését. A közelmúltban bankmúveletek megkezdéséhez kért licencet a Facebook, de banki jogosítványt igényelt a Robinhood, a világ egyik első díjmentes értékpapír-kereskedelemmel foglalkozó cége is. Kérdés, miért indult el a Facebook és később a Google is ebbe az üzleti irányba? A válasz egyszerű: óriási tömegű felhalmozott adattal rendelkeznek, és a PSD2 ${ }^{8}$ szabályozása a banki ügyfelek adatainak hozzáférésével tágra nyitotta számukra a pénzforgalmi szolgáltatások kapuját, mintegy lavinát indított el.

Ennek az egész digitális folyamatnak új és váratlan fordulatait szolgáltatta a Facebook. Miután a Facebook adatfelhasználását és -kezelését számos kritika érte, 2019 tavaszán Mark Zuckerberg, a közösségi oldal alapítója és vezetője a The Washington Postban megjelentetett nyílt levelében az internet törvényi szabályozására és ellenőrzésére kérte a kormányokat. Pár hónappal később 5 milliárd dolláros bírság kifizetésében állapodott meg a Facebook a Cambridge Analytica-botrány miatt

${ }^{8}$ Revised Payment Services, Directive (EU) 2015/2366 (második pénzforgalmi irányelv) 
indított vizsgálat végén. A bizalomvesztést is eredményező folyamat során Mark Zuckerberg az amerikai Szenátus meghallgatásán is megjelent, ahol számos etikai és bizalomerősítő intézkedést jelentett be és ígért az adatkezeléssel kapcsolatban. „Nos, a Facebook lehet, hogy nem akar veszélyes lenni, de az bizonyos, hogy nem tisztelik az általuk alkalmazott technológia hatalmát. Olyanok, mint egy kisgyerek, aki kezébe kerít egy doboz gyufát, a Facebook már többször és ismét felgyújtotta a házat, és minden gyújtogatást tanulási kísérletnek hívott. A Facebooknak két egymással versenyzö küldetése van, a világot nyitottabbá, összekapcsolttá tenni és sok pénzt keresni. Miközben mindkét küldetésének meg akar felelni, mindnyájunk számára pusztítást okoz" (Brown 2019:1).

Az újabb fordulatot a Facebook Libra nevú saját kriptopénzének bevezetése jelentette, ami aggodalmakat keltett az amerikai központi bankban, a FED-ben és az ECB-ben is. Ezt a Facebook-eseménysorozatot azért kell megemlíteni, mert rávilágít a digitálisan megszerzett, tárolt és sokoldalúan felhasznált adatok kényes voltára, kiváltja a szabályozási ingert (utólag látva, hogy lényeges eredmény nélkül), továbbá megjeleníti, hogy ez az óriási adattömeg még egy mesterséges, monetáris szempontból alig kezelhető kriptopénz-kibocsátásnak elvi lehetőségét is megteremti.

Visszatérve a PSD2-vel indított fenti gondolathoz, arra kell emlékeztetnünk, hogy az lehetővé teszi, hogy FinTech-cégek kezdeményezhessenek online átutalásokat a felhasználó nevében, és továbbítsák ezeket az utasításokat egy banknak, vagy további szolgáltatásokat nyújtsanak, mint például a hitelezés. Lehetővé válik számukra az egyén kiadási viselkedésének részletes elemzése. Ebbe a körbe tartozik az az új típusú információmegosztást lehetővé tevő FinTech-szolgáltatás is, amelynek a rövidítése AISP (Account Information System Provider) és a fizetéskezdeményezési lehetőség, a PISP (Payment Initiation Service Provider), amelyet ezek a szolgáltatók biztosíthatnak.

Mint látható, a szabályozók kettős szerepe tovább erősödik. A támogató magatartás egyre bővül, ugyanakkor az új belépők a pénzügyi szolgáltatások olyan széles körét képviselik, hogy egy részletes szabályozás ezt csak utolérni igyekezhet. Az FSB és az ECB által is markánsan megfogalmazott problémák miatt, a tételes szabályozás hézagos vagy nem létező kihatásaira tekintettel az utóbbi időben egyre gyakrabban kerül előtérbe kiegészítő követelmények megfogalmazása. Ilyenek például a bizalom építése érdekében a kötelező gondosság, magatartási és etikai normák kialakítása, alkalmazása és megkövetelése. Ezeket a fejleményeket tekintjük át, amelyek paradigmaváltást jeleznek.

A szabályozás igényének egyfajta előfutára a Global Financial Innovation Network (GFIN) kezdeményezése, amely határokon átnyúló regulatory sandboxot hozott létre innovatív pénzügyi termékek és szolgáltatások tesztelése céljából. A GFIN elnöke, Andrew Bailey, aki egyben a brit Financial Conduct Authority (FCA) vezetője, be- 
jelentette, hogy a szervezet 29 ország szabályozó testületét egyesíti, és tesztelési célból már közel 50 FinTech-cég jelentkezett. Az FCA ebben a helyzetben arra törekedett, hogy a szabályozás kívánsága és a tisztességes FinTech-magatartás megteremtése között nemzetközileg is használható hidat építsen: „Támogatom a sikeres, nyílt pénzügyi piacokat, ahol szabad a kereskedelem és nem kötődik piaci helyszínekhez, ahol a piac globális és nem szúkösen regionális. De, és ez egy nagy „de”, mindezt tisztességes és fenntartható módon kell megvalósítani, ami igazságos a társadalom minden csoportjával szemben, és visszatükrözi bármely létező társadalmi szegmens képességeit és sebezhetöségét. A közérdek megköveteli, hogy a sikert a méltányossággal és a fenntarthatósággal kombináljuk" (Bailey 2019:1).

Ennek keretében bevezetik a gondossági kötelezettség fogalmát, aminek alkalmazása a FinTech-vállalatokat arra kötelezi, hogy vizsgálják tevékenységük során, hogy „ez helyes volt-e”, nem pedig azt, hogy „ez a szabályoknak megfelelt-e”? Világossá tennék a fogyasztók számára, hogy mit várhatnak és/vagy igényelhetnek a FinTech-vállalatoktól, és kialakítana egy egységes, átfogó gondoskodási koncepciót, amely segítene a fogyasztói bizalom helyreállításában. Ebben az értelemben a kötelező gondosság, aminek az angol eredetije a „duty of care”, tartalmában egy magatartási formát jelent, ami segíti az új típusú banki, illetve FinTech magatartási kódexek kidolgozását. A kezdeményezésről röviden annyit, hogy tükrözi azt a felismerést, hogy az ilyen típusú szolgáltatásokat szabályozni kell, de nem jut tovább a bizalomépítő gondossági normák megfogalmazásánál. Mint láttuk, a nemzetközi együttmúködésre nagy szükség lenne a szabályozás terén. Ennek kezdeményezésére, építésére jó példa Ausztria, ahol a pénzügyminiszter bejelentette, hogy az FCA-val szoros együttmúködésben regulatory sandboxot fejlesztenek ki, ami újabb lépés egy nemzetközi egységes megközelítés irányába. „A tavalyi évben létrehozott FinTech Tanácsadó Testület segít kialakítani azokat a szabályokat, amelyek irányítják a digitalizált pénzügyi szolgáltatások körül létrejövő fiatal pénzügyi piacokat. A regulatory sandbox kezelése biztosítja a szükséges felügyeleti rálátást, ugyanakkor ösztönzi az innovációt és a növekedést" (Loeger 2019:1).

Az osztrák példához hasonlóan a Magyar Nemzeti Banknak is szoros szakmai kapcsolata van az FCA-val és csatlakozott a GFIN-hálózathoz. „E hálózat célja a hatóságok és az innovativ piaci szereplők nemzetközi együttmüködésének elősegítése, a FinTech-megoldások globális szintü terjedésének közös támogatása. A nemzetközi hálózat keretet ad arra, hogy az országok közötti információ- és tapasztalatcsere a FinTech-innovációkról - illetve kifejezetten a szabályozói elvárások teljesítése érdekében igénybe vett innovativ megoldások, az ún. Regtech-fejlesztések kapcsán -formalizáltan, hatékonyan történjék" (MNB 2019:1). 
Ebben a „kórusban” megszólaltak az összehangolt uniós szabályozás szempontjából fontos Európai Felügyeleti Hatóságok (European Supervisory Authorities, ESA). „A pénzügyi technológia (FinTech) átalakítja a pénzügyi szolgáltatásokat. Ez megkönnyíti a pénzügyi szolgáltatásokhoz való hozzáférést és kényelmesebbé teszi őket. Növeli a müködési hatékonyságot és csökkenti a fogyasztók költségeit. Ezáltal csökkentheti az új piaci szereplök piacra lépésének akadályait, és növelheti a versenyt. Ahhoz, hogy ezek az elönyök megvalósuljanak, fontos biztosítani az informatikai rendszerek integritását és rugalmasságát, az adatvédelmet, valamint a tisztességes és átlátható piacokat. E célkitüzés elérése megköveteli, hogy az illetékes hatóságok között erösítsék a technológiai innováció tekintetében a közös uniós felügyeleti kultúrát. Ezen belül az Európai Felügyeleti Hatóságok azt a feladatot kapták, hogy koordinálják a nemzeti felügyeletek által létrehozott technológiai innovációs eszközöket és módszereket, például az innovációs csomópontokat vagy a regulatory sandboxokat. Fontos feladatnak tekintik a technológiai tudatosság fejlesztését valamennyi nemzeti felügyelettel együttmüködve, ide értve a számítógépes fenyegetéseket és a támadásokkal kapcsolatos információmegosztást is" (ESA 2019:1-2).

Ismét megjelent egy fontos irányelv, de a gyakorlatban ez sem lép tovább annál az elvárásnál, hogy az EU illetékes hatóságai erősítsék a pénzügyi piacok terén a technológiai innovációk közös uniós felügyeleti kultúráját.

\section{A bizalom építményének alapjai a FinTech világában: a szabályozás és az etika viszonya}

A fentiekben áttekintettük a bizalom és az etika „újkori” szerepét, időbeni megjelenését a hagyományos bankok és a FinTech-szolgáltatók esetében. Olyan időszakban van a nemzetközi és a hazai bankrendszer egyaránt, amikor a digitális fejlődés miatt a pénzügyi és bankrendszer minden szereplőjének új kihívásokkal kell szembenéznie. A legutóbbi pénzügyi válság óta immár egy évtizede nyugodt gazdasági körülmények között fejlődött a fenntartható gazdasági növekedés finanszírozása, megindult az egészséges verseny a bankpiacon. Ebben a majdnem idilli helyzetben merültek fel azok a megválaszolandó, nehéz, vagy talán újszerü kérdések, amelyeket írásunk elején feltettünk. Az Európai Unió tagjaként a pénzügyi közvetítő rendszer múködési környezetét, szabályozását, bizalmi és etikai kérdéseit elsősorban az uniós és hazai összefüggések kertében vizsgáltuk. A 2008 utáni időszakban az Európai Unióban a bankszektor biztonságos múködését erősítő egész szabályozási arzenál és intézményi architektúra alakult ki. Jelentősen előrehaladt a Gazdasági és Monetáris Unió, a Bankunió és a Tőkepiaci Unió építkezése. Árnyaltabb, egységesebb és a bankrendszer biztonságosabb múködését segítő szabályozó rendszer alakult ki. 
Ekkor azonban beléptek a piacra a digitális pénzügyi fejlődés szereplői, a FinTech, majd nem sokkal később a BigTech, vagy akár a harmadik fél (TPP) szolgáltatók. Egyre erősödő piaci térnyerésük döntések elé állította a központi bankokat, felügyeleteket, szabályozókat és magukat a hagyományos bankokat is.

A nemzetközi és nemzeti szabályozó szervek egyre határozottabban jelezték, hogy a FinTech-folyamatok a pénzügyi piacokon kockázatokat, a pénzügyi közvetítő rendszer folyamatait felforgató hatást hordoznak. Szükség lenne egy átfogó nemzetközi és nemzeti szabályozásra, amely a kockázatok csökkentése mellett megteremtené az egyenlő versenyfeltételeket a hagyományos bankok és a FinTech/BigTech cégek között. Szembesülni kellett azzal, hogy bonyolult, a szabályozás tárgyának konkrét definícióját is csak körülírni képes helyzetben, rendszerkockázati, prudenciális, fogyasztóvédelmi és adatvédelmi szabályokat kellene megalkotni. Mindezt úgy, hogy a digitális pénzügyi szolgáltatások többsége határokon átnyúló, így el kellett volna dönteni, hogy hol, ki és mit szabályoz. Ebben a helyzetben az Európai Központi Bank állásfoglalása az, hogy jelenleg a FinTech-szolgáltatásokat nemzeti hatáskörben kell kezelni. Annak érdekében, hogy a szabályozó hatóságok a folyamatokhoz fel tudjanak zárkózni, áthidaló, a szabályozást átmenetileg helyettesítő megoldásokat kell találni.

Első lépésként elfogadottá vált, hogy a FinTech-vállalkozások piacra lépését támogatni kell, ezért hoztak létre inkubátorházakat, regulatory sandboxokat. Ezektől két hatást vártak, egyrészt a startup vállalkozásokkal megismertetni az elvárt szabályos tevékenység követelményeit, másrészt belelátni és megismerni szolgáltatásukat, hogy ennek az ismeretnek a birtokában lehessen majd a szabályokat kidolgozni.

A tételes szabályok nélküli időszak következő szakasza a viselkedési és etikai normák, gondossági szabályok megfogalmazása és betartatásának igénye volt, remélve a bizalomépítés alapjainak lerakását is. Olyan terület ez, ahol a tradicionális bankoknak hagyománya és tapasztalata volt és van. A digitális pénzügyi szolgáltatások gyors fejlődése, piaci térhódítása felgyorsította ezt a folyamatot, de rögtön a kezdetben megjelent egy alapkérdés, hogy ha etika, akkor kinek az etikája? A hagyományos bankok etikai kódexeivel kapcsolatban ez a kérdés nem merülhetett fel, mivel az etikai, tisztességes magatartási követelmények az adott pénzintézet szolgáltatásaira, az azokat elóállító és nyújtó alkalmazottakra vagy akár a bank menedzsmentjére vonatkoztak. Amint láttuk, szerepük bizalomerősítő volt, annak igazolása, hogy a bank a szabályokat betartja, és üzletvitele ezenfelül még etikus is.

A FinTech világában ez az etikai képlet és struktúra megváltozik. Az első lényegi különbséget az időbeliség jelenti, mivel a hagyományos bankok esetében, mint láttuk, az etikai normák egy-egy megrázkódtatást követően, a bizalom helyreállítása érdekében kerültek előtérbe. A FinTech típusú pénzügyi szolgáltatásokat a felhasználók meghatározó többsége pozitívan fogadja, mondván, hogy a szolgáltatás gyors és 
olcsó, gyanakvásuk, kockázatérzékenységük nincs. Ahol viszont egyre gyakoribbak a panaszok és a kritikai észrevételek célpontja az adathalászat, az a személyes adatok, elsősorban az úgynevezett hátrahagyott adatok olyan gyújtése és felhasználása, amelyről az adat tulajdonosa nem is tud. Ezért szembesülünk egy olyan helyzettel, amikor az etikai, viselkedési, magatartási, gondossági normák elsősorban arra lennének hivatottak, hogy helyettesítsék a késlekedő tételes szabályokat. Ezek a FinTech etikai szabályok egy nyugodt gazdasági és pénzügyi környezetben jelennek meg. A hagyományostól eltérő másik jellemzőjük, hogy nem, vagy nem csak a nyújtott szolgáltatás végeredményére, például pénzforgalmi szolgáltatásokra vonatkoznak. Korábban említettük, hogy az FSB és az ECB is fontosnak tartja a FinTech-tevékenység megkezdésének tételes engedélyezését, ami helyes, de azonnal látjuk, hogy ezek ez engedélyek korlátozottan lesznek képesek kezelni a tevékenység hátterét adó adattömeget vagy a mesterséges intelligencia igénybevételét.

Fentieknek megfelelően a ma már létező, de nem elégséges szabályozás miatt etikai, irányelv jellegű alkalmazási normákkal igyekeznek „,szabályozni” a FinTech/BigTech pénzügyi szolgáltatások eszköztárát, azaz a mesterséges intelligenciát, a nagy adatok és hátrahagyott adatok felhasználását.

Számos példa van arra, hogy különböző országokban megjelenik a tételes szabályozásra való törekvés. Egyik példaként említjük az Egyesült Államokat. A potenciális kockázatokat mérlegelve az amerikai demokrata párti képviselők - a Szenátus Pénzügyi Szolgáltatások Bizottságában - a Federal Reserve System Kormányzó Tanácsa álláspontjára hivatkozva olyan törvényjavaslatot terjesztettek elő, amely szerint a nagy platform felhasználásával múködő BigTech-cég nem hozhat létre, tarthat fenn és üzemeltethet digitális eszközt/programot, amelyet széles körben használnak átváltási eszközként, elszámolási egységként, értékmegőrzőként vagy más hasonló funkciók ellátására.

Felismerve és deklarálva a pénzügyi közvetítő rendszerre és a pénzpiacokra kiterjedő kockázatokat, elindult egy folyamat az etikai, gondossági keretek kialakítása érdekében. Ennek szerves részeként terjesztették ki a bevezetni szándékozott normákat a FinTech-vállalkozások által igénybe vett eszközökre is. Az Európai Bizottság 2019 áprilisában tette közzé az „Etikai iránymutatás a megbízható mesterséges intelligenciára vonatkozóan” című dokumentumot (Európai Bizottság 2019a). Az irányelvek szerint „az Al-rendszereknek emberközpontúnak kell lenniük, és felhasználásuknak továbbra is az emberiség és a közjó, valamint az emberi jólét és szabadság fokozásának célját kell szolgálniuk. Az Al-rendszerek amellett, hogy remek lehetőségeket kínálnak, bizonyos kockázatokat is előidéznek, amelyeket megfelelöen és arányosan kell kezelni. Jelenleg jelentős mértékben van lehetőségünk arra, hogy befolyásoljuk ezek kialakulását. Biztosítani kívánjuk, hogy meg lehessen bízni azokban a társadalmi és müszaki környezetekben, amelyekbe a mesterséges intelligenciát beágyazzuk, 
és azt kívánjuk, hogy az Al-rendszerek elöállítói a megbízható mesterségesintelligencia-termékekbe és -szolgáltatásokba történő beágyazása révén versenyelőnyhöz jussanak. Ehhez törekedni kell arra, hogy maximalizáljuk az Al-rendszerek elönyeit, közben pedig meg kell előzni és minimalizálni kell azok kockázatait. Úgy hisszük, hogy a gyors technológiai változással összefüggésben lényeges, hogy a bizalom maradjon a társadalmak, közösségek, gazdaságok és a fenntartható fejlödés kötőanyaga. A megbízható mesterséges intelligenciát ezért alapvető ambíciónkként határozzuk meg, mivel az emberek és közösségek kizárólag akkor lesznek képesek megbízni a technológia fejlődésében és annak alkalmazásaiban, ha e megbízhatóság elérését biztosítjuk." (Európai Bizottság 2019a:1-2).

A Bizottság dokumentuma meghatározza az etikus mesterséges intelligencia követelményét: „A megbízható mesterséges intelligencia megvalósítása érdekében nem csak a jognak kell megfelelni, mivel ez a megbízható mesterséges intelligencia három alkotóelemének pusztán az egyike. A jogszabályok nem mindig tudják tartani a lépést a technológiai fejleményekkel, időnként elöfordulhat, hogy nem felelnek meg az etikai normáknak, vagy bizonyos kérdések kezelésére egyszerüen nem alkalmasak. Ahhoz, hogy az Al-rendszerek megbízhatók legyenek, etikusaknak is kell lenniük az etikai normákkal való összhang biztosítása révén. Társadalmunk csak akkor élvezheti teljes mértékben a technológiai vívmányokból származó elönyöket, ha maga a technológia megbízható. A mesterséges intelligencia etikus megközelítéséből mindenki profitálhat, Európa pedig versenyelönyhöz juthat általa: vezető pozíciót tölthet be az emberek számára megbízható, emberközpontú Al-termékek gyártásában" (Európai Bizottság 2019a:3).

A Bizottság többlépcsős megközelítést javasol a megbízható, etikus, emberközpontú Al-re vonatkozó alapvető követelmények meghatározása során. Ennek értelmében a megbízható Al-nek tiszteletben kell tartania minden törvényt és előírást. Az ehhez használt értékelési listák célja, hogy segítsenek ellenőrizni, azonosítani a kulcsfontosságú követelmények alkalmazását, például emberi képviselet és felügyelet; biztonság; adatvédelem és adatkezelés; átláthatóság; társadalmi és környezeti jólét; elszámoltathatóság. Megbízható Al rendszerek nem múködhetnek, ha nem alakul ki nemzetközi konszenzus az emberi központú Al-re vonatkozóan. Az Európai Bizottság kívánatosnak tartaná, ha az Al-etikára vonatkozó megközelítés globálisan lépne érvénybe, mivel a technológiák, az adatok és az algoritmusok nem ismerik a határokat. E célból a Bizottság megerősíti az együttmúködést hasonló gondolkodású partnerekkel (pl. Kanada és Japán). Az Európai Bizottságnak ez a célkitűzése mérföldkövet, bizonyos értelemben áttörést jelent.

A kompetens hatóságok mellett az etikai alapvetések vizsgálata megjelent a tudományos kutatások palettáján is. 2017-ben az Oxford Internet Intézet létrehozta a Digital Ethics Lab (“DELab") nevű intézményét, amelynek feladata a digitális innovációk 
etikai kihívásainak vizsgálata, mivel ezek a kérdések áthatják a technológia, a tudomány, a jog, az üzleti élet, és végül, de nem utolsó sorban a társadalom egészét. „A DELab célja, hogy azonosítsa előnyeit, erősítse a digitális innováció által kínált pozitiv lehetőségeket, és segítsen elkerülni vagy csökkenteni kockázatait vagy hiányosságait" - mondta az intézet vezetője, Luciano Floridi, az informatika filozófiájának és etikájának professzora. 2019-ben a Blackstone amerikai tőkealap 190 millió dolláros támogatásával kifejezetten a mesterséges intelligencia etikai oldalával foglalkozó kutatóközpontot alapítottak, az Oxford Al-Etikai Intézetet (Oxford's Al Ethics Institute), amelynek alapításakor hangsúlyozták az Al-etika kutatásának fontosságát, mert a mesterséges intelligencia hatásainak kezelésére nincsenek felkészülve a világ kormányai, így az ezzel kapcsolatos szabályok megalkotásakor szükséges a feltárt etikai és magatartási normák ismerete.

Mivel az intelligens és értelmes gépeknek az Al-re támaszkodva végzett tevékenysége a FinTech-szolgáltatások megvalósításának egyik fontos eleme, annak etikai követelményeit, a szükséges jogszabályi keretek hiányát is figyelembe véve számos kutató vizsgálta. Két ismert kutató megállapításait emeljük ki: „A mesterséges intelligencia nagy adatokra és gépi tanulásra támaszkodik, ami számos alkalmazás számára szükséges. A nagy mennyiségü adat rendelkezésre állása elengedhetetlen az Al fejlödéséhez. Azonban a Facebook és a Cambridge Analytica személyes és társadalmi adatainak használatával kapcsolatos közelmúltbeli botrány etikai megfontolásokat hozott elötérbe. És ez csak a kezdet. [...] Hogyan tudnánk jobban tudatosítani az ilyen felelösséget, ha nincs globális szabályozás az Al-val kapcsolatban? Az Al és az ahhoz kapcsolódó technológiák értékelésének etikai normái még mindig gyerekcipőben járnak. [...] Figyelembe véve a téteket és az Al adatéhségét, valószínüleg arra kényszeríti a vállalatokat, hogy kellemetlen kérdéseket tegyenek fel. Az elsö tanulság, hogy az etikus magatartás vizsgálata elengedhetetlen az Al felhasználásával végzett tevékenység során, ami döntő fontosságú lesz a digitális világ elfogadásához. Ahhoz azonban, hogy az Al teljesítse az ígéretét, kiszámíthatóságra és bizalomra van szükség. Ez a kettő összekapcsolódik. Az Al által felvetett, összetett kérdések kiszámítható kezelése, mint például az elszámoltathatóság és az adatok megengedett felhasználása, bátorítani fogja az Al-befektetéseket és azok használatát. Hasonlóképpen az Al elörehaladása megköveteli a fogyasztók bizalmát, hogy bízzanak a technológiában, annak rájuk gyakorolt hatásában, és abban, hogy hogyan használják fel az adatokat. A kiszámítható és átlátható szabályozás előmozdítja ezt a bizalmat" (Guillén - Reddy 2018:1-2).

Az elmúlt időszakban számos állítás jelent meg arra vonatkozóan, hogy üzleti vállalkozások az Al-t nem etikusan használták. Vélelmezhető, hogy ez a kritika nem volt alaptalan, mert az Amazon, a Google, a Facebook, az IBM és a Microsoft létrehozott egy nonprofit partnerséget a mesterségesintelligencia-technológiák legjobb gyakorlatának megfogalmazására, a közvélemény megértésének segítésére. Ezt a példát 
azért emeljük ki, mert az öt globális felhasználó arra a következtetésre jutott, hogy a szabályozás hiányában maguk alakítanak ki egy önszabályozás jellegű, bizalmat erősítő adatkezelési platformot.

A fenti áttekintés alapján össze tudjuk hasonlítani azt a folyamatot, ahogyan a hagyományos bankok és a FinTech típusú pénzügyi szolgáltatók bizalmi és etikai normái alakulnak. Olyan fejlődési folyamattal szembesülünk, amelyet képletesen egy homokórával lehet érzékeltetni. Látni fogjuk, hogy a szabályozás és az etikai, morális, magatartási követelmények sorrendje, súlya teljesen megváltozik a bankok és a FinTech/BigTech vállalatok vonatkozásában, megfordul a hagyományos sorrend. A hagyományos bankok esetében általában, de a legutóbbi nemzetközi pénzügyi válság után kényszerűen, nagy tömegű szabályozás, veszteség- és kockázatcsökkentő intézkedés lépett hatályba. Amikor túljutunk a válság okozta rombolás utáni helyreállítás nagyobbik hányadán, időszerűvé és szükségszerűvé válik a bizalomépítés, mindenekelőtt az ügyfelek bizalmának visszaszerzése. Ennek klasszikus eleme az etikai és magatartási normák újragondolása és deklarálása. Ezek az etikai kódexek nem helyettesítik a szabályozást, arra ráépülnek, azt erősítik. (Egyedi kivétel az idézett, 2015-ben kidolgozott magyar etikai kódex, amely akkor jogérvénnyel bírt.) A homokóra ábra felső szegmense jellemzi ezt a folyamatot.

A FinTech piaci térhódításának következményeit az óra alsó tartománya szemlélteti. A digitális pénzügyi szolgáltatók megjelenésekor a szolgáltatásaikat igénybe vevők elégedettek voltak, jól fogadták a gyorsaságot, az online ügyintézést és az alacsonyabb költségeket. Megvolt a bizalom, amit talán helyesebb úgy fogalmazni: nem volt bizalmi deficit.

Az ismertetett okok miatt (rendkívül gyors térnyerés, pénzügyi közvetítő rendszer szabályos működését sértő fejlemények, adatszerzési és felhasználási anomáliák, szabályozás hiánya és késlekedése) a digitális pénzügyi szolgáltatások terén nyilvánvalóvá váltak bizonyos kockázatok, amelyeket etikai, viselkedési, gondossági kódexekkel és önszabályozással igyekeztek keretek között tartani. Az időben előre haladva viszont egyre erősödik a szabályozás követelménye. Ezt a fejlődési szakaszt jeleníti meg a homokóra alsó tartománya (2. ábra). 


\section{2. ábra}

Homokóra: a banki és FinTech-etika időbelisége

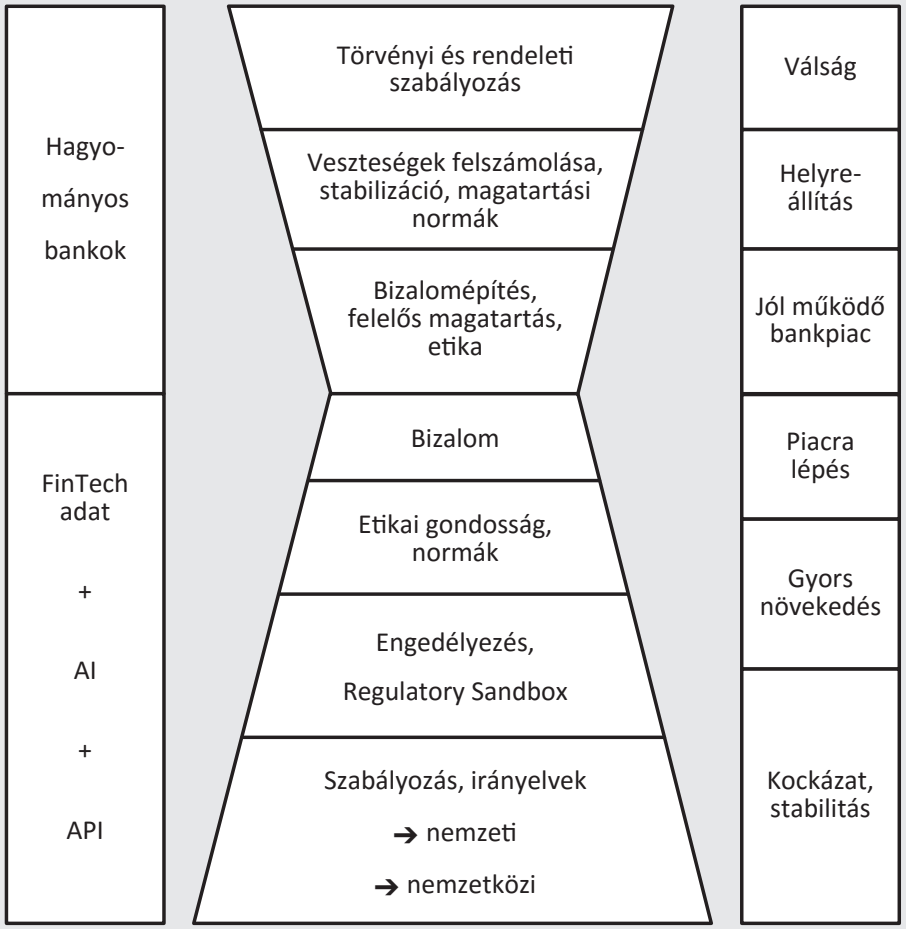

A jelenleg ismert FinTech etikai követelményekben természetesen megjelennek a hagyományos banki etikai kódexek hívószavai, mint például a tisztességes üzleti magatartás, a transzparencia elve, a gondosság vagy a szabályok betartásának követelménye. Van azonban két különbség. Egyrészt a hagyományos bankok esetében az etikai normák a megvalósított és „eladott” banki termékre (például hitelezésre), az azzal kapcsolatos üzleti magatartásra irányulnak, a kódexek bankon belüli része pedig a bankok munkatársainak etikus viselkedéséhez ad iránymutatást. A FinTech-etika ugyanakkor szolgáltatásaikkal kapcsolatban többnyire a tranzakcióalapú tevékenység gondos megvalósítását erősítik. A szolgáltatás megvalósításánál viszont már nem az ember, hanem a mesterséges intelligencia, a robottechnika kerül a középpontba. Az adatfelhasználási és kezelési problémákat észlelve megjelent az a követelmény, hogy az alkalmazott mesterséges intelligenciára külön Al-etikai normákat kell megfogalmazni. Ezeknek sajátossága, újszerűsége, hogy nem árthatnak az embernek, emberközpontúnak kell lenniük, a robottechnika nem fordulhat az ember ellen. Ebben a keretrendszerben vizsgálják például a döntéshozatal felelősségét. Így az Al használata során hogyan lehet megosztani a felelősséget a döntésekért, 
ha károkat okozó hibák történnek, ki viseli a kockázatot? Más oldalról közelítve: ha a jelentős döntések meghozatalához komplex gépi tanulási rendszereket alkalmaznak, az adott cselekvési folyamat mögött álló okokat csak akkor lehet feltárni, ha érvényesül a transzparencia elve. Az adat- és internet-védelemmel kapcsolatban etikai oldalról is vizsgálják az Al-nak azt a nagy erejét, amely a nagy adathalmazokhoz való hozzáférésben gyökerezik. Mi történik, ha egy Al-rendszert egy adatkészleten képeznek, majd egy új adathalmaz tanulására alkalmazzák? Az etikai iránymutatás szerint a felelős Al gondoskodik az erkölcsi elvekről és értékekről, annak biztosítása érdekében, hogy az alapvető emberi etika ne sérüljön.

A FinTech-, illetve az egyéb digitális alapú pénzügyi szolgáltatásokra vonatkozóan az Európai Bizottság ismét felhívta a figyelmet, hogy a lehetséges kockázatokat csökkenteni, az azokat támogató bizalmi hálót erősíteni kell. Az Európai Bizottság közzétette a mesterséges intelligencia alkalmazásával kapcsolatos iránymutatását: „A mesterséges intelligencia esetében az etikai szempontok nem tekinthetők csupán luxusnak, és nem szorulhatnak a háttérbe." (Európai Bizottság 2019b:1). A Bizottság többlépcsős megközelítést alkalmaz a megbízható, etikus, emberközpontú Al-re vonatkozó alapvető követelmények meghatározása során.

\section{Napfény és árnyék, napfény vagy árnyék? Összefoglalás}

Amióta a negyedik ipari forradalom részeként megjelentek a digitális pénzügyi szolgáltatások, és piaci részarányuk, a szolgáltatásaikat igénybe vevők száma gyorsan nőtt, tevékenységük következményeit minden érintett elemezte, ide értve magukat a FinTech-vállalkozásokat is. Örömmel és ujjongva fogadták az innovatív szolgáltatásokat gyorsaságuk, olcsóságuk miatt a felhasználók, kockázati jellegű bizalmatlanság bennük fel sem merült. Támogatták indulásukat a gazdaságpolitikai döntéshozók és a felügyeletek is, mondván, hogy a nemzetközi versenyben való helytállás nélkülözhetetlen eleme a digitális fejlesztések gyors üteme. A hagyományos bankok a kezdeti időszakban nem tartották komoly kihívóknak a FinTech-startupokat, mivelhogy vagy készítenek hasonló fejlesztéseket, vagy beolvasztják a legjobb startupokat. Boldogok voltak a FinTech-vállalkozások is, mivel szellemi értékű fejlesztéssel, alacsony tőkeigénnyel, laza szabályok mellett gyorsan fejlődő és jól jövedelmező vállalatokat lehetett alapítani. El lehet mondani, hogy a FinTech-fejlődésnek ez volt a napfényes aranykora.

A gyors, szerteágazó fejlődés, új típusú szereplők belépése megjelenített és előrevetített olyan problémákat, amelyeket azonosítani kellett, és megoldásokat kellett rájuk találni. Az FSB 2019-ben már megállapította, hogy a FinTech-folyamatok megbonthatják a pénzügyi struktúrát, és veszélyt jelenthetnek a pénzügyi stabilitásra, az Európai Központi Bank pedig hangsúlyozta az egyenlő versenyfeltételek, az azonos szolgáltatások, azonos szabályok betartásának megvalósítását. 
Ezeknek az induló feltételeknek és gyors fejleményeknek elemzése azt mutatta, hogy már nem elégséges adott pénzügyi szolgáltatás és szolgáltató felügyelete és szabályozása, azt ki kell terjeszteni a szolgáltatás hátterét képező eszközökre, például a mesterséges intelligenciára is. Az átfogó és összehangolt szabályozás kialakítása még időt igényel, helyettesítőként beléptek az etikai és önszabályozási magatartási követelmények.

A tanulságok és következtetések érdekében összefoglaltuk a bizalom, megbízhatóság és etika követelményét mint a hagyományos bankok sikeres működésének hagyományos értékét. Ezt követően tekintettük át a digitális pénzügyi folyamatok szabályozási helyzetét, igényét.

A vizsgált folyamatot szakaszokra bontva jellemeztük. A nemzetközi pénzügyi válságot követően helyreállt a hagyományos bankok múködése, megerősödött bizalmi és etikai tőkéjük. Digitális pénzügyi szolgáltatásokat kínálva kihívóként megjelentek a FinTech-startupok. Felbukkanásukat támogatás, fogyasztói bizalom fogadta, a bankok és a szabályozók piaci szerepüket marginálisnak, kockázatmentesnek tekintették. Az elmúlt évtized második felében a FinTech térhódítása forradalmian gyors volt, és három típusú veszélyforrás jelent meg. A hagyományos bankok jelezték, hogy a szabályozás nem biztosítja az egyenlő versenyfeltételeket, és a PSD2 szabály módosítása jelentős adat- és piacvesztést eredményez számukra, amennyiben maguk nem indítanak jelentős költségvonzatú digitális fejlesztéseket. A nemzetközi szabályozó hatóságok figyelmeztető jelzéseket adtak ki a piaci struktúra gyors átalakulását, pénzügyi stabilitási problémákat és olyan versenyt kikényszerítő elemeket megjelölve, amelyek mikro- és makropénzügyi kockázatokat jelentenek. A potenciális pénzügyi stabilitási problémák elhárítása érdekében megjelent a FinTech nemzeti és nemzetközi szabályozásának igénye. Az ehhez szükséges eszközök vizsgálata során szembesültek azzal, hogy nem elégséges önmagában a FinTech-szolgáltatókat és -termékeket szabályozni. Potenciális kockázatokat hordoz az általuk felhasznált adattömeg, a mesterséges intelligencia vagy a nagy adatokat feldolgozó algoritmusok.

A mindenre kiterjedő szabályozás azonban nem teljesült, megjelentek áthidaló javaslatok, mint például az engedélyezési útmutatók. Szabályozás hiányában a bizalom építésének szükségessége nyilvánvaló, ezért valós áttörést jelentett a magatartási kódexek, etikai normák, a viselkedési gondosság, nemzetközi regulatory sandboxok megjelenése.

A 2010-es évek közepén a bankszektor túljutott a pénzügyi válság okozta legnagyobb károkon, megindult a gazdaság fenntartható finanszírozása. Napirendre került a válság okozta banki túlszabályozás normális mederbe terelése, és központi feladattá vált a bankrendszerrel szembeni bizalom újraépítése. Ennek a folyamatnak lényeges építőeleme volt a banki etikai normák és magatartási kódexek újragondolása. 
A bekövetkezett nyugodt, békés fejlődési időszakban felgyorsult a negyedik ipari forradalom, annak minden lényeges eleme belépett a globális gazdasági térbe, a mesterséges intelligenciától a robottechnikáig. A hagyományos bankok hosszabb ideig érdemi kritika vagy ellenkezés nélkül tekintettek az új FinTech-szereplőkre, magabiztosan nyilatkoztak, hogy alapvető banki szolgáltatásaikat nem tudják átvenni, piaci részesedésük marginális marad, a sikeres innováció tulajdonosaival vagy együttműködési, vagy fúziós megállapodást kötnek. A folyamat első szakaszában inkább csak azért emeltek szót, hogy egyenlőtlen, azaz a szabályozási feltételek miatt a FinTech-cégek számára kedvező a múködési környezet, és számukra egyenlőtlenek a versenyfeltételek. Kockázati aggodalmak, bizalmi kérdések sem a szabályozók, sem a digitális pénzügyi szolgáltatásokat igénybe vevők részéről nem merültek fel. Összefoglalva e fejlődési szakasz jellemzőit elmondható, hogy ragyogó napfényben, támogatással és piaci kereslettel bővült a FinTech-startupok köre.

Persze minél erősebb a napfény, annál markánsabbak az árnyékok. Több tényező rövid időn belül való megjelenése figyelmeztetett arra, hogy kockázatok vannak vagy várhatók, megnő és sötétebbre válik az árnyékos terület. Az a felfogás alakult ki, hogy jobb támogatni és így közelebbről megismerni a FinTech-startupokat, és a szabályozással követni a fejlődést. A támogatás eszközei változatosak voltak a regulatory sandboxoktól az innovációs hubokig, egészen addig, amíg megjelent a PSD2 szabályozás módosítása, lehetővé téve a FinTech-cégek számára a banki ügyféladatok egy részéhez való hozzáférést.

Ezen a ponton mérföldkőhöz érkeztünk. A digitális pénzügyi szolgáltatások a hagyományos bankok piacának és jövedelmének jelentős részét hasították ki. Ezzel párhuzamosan piacra léptek az úgynevezett BigTech-cégek, amelyek már nemcsak pénzforgalmi szolgáltatásokat, hanem hitel, betéti és biztosítási termékeket is ajánlottak, gyors lebonyolítással és rendkívül alacsony költségszinten. Egyebek között olyan óriáscég, mint a Facebook is banklicencet kért és kapott. A TechCrunch hivatalos közleménye szerint a Facebook Payments International LTD (FBPIL) 2016. október 24-én elektronikus pénzintézetként licencet kapott az Ír Központi Banktól (Central Bank of Ireland, CBI), ami lehetóvé teszi az elektronikus pénzkibocsátást, pénzforgalmi szolgáltatásokat és átutalásokat (credit transfer).

Ezek a digitális pénzügyi szolgáltatók müködésükhöz igénybe veszik a digitális technológia minden elérhető elemét, a nagy adatokat, a mesterséges intelligenciát, az API adatelemző módszereket, a robottechnikát, a hátrahagyott adatok felhasználását.

A hagyományos bankok ráébredtek, hogy lépéskényszerbe kerültek, és 2017-től jelentős digitális fejlesztéseket végeztek, felgyorsították digitális felzárkózási folyamatukat, a hatóságoknál pedig igényelték az egyenlő versenyfeltételek biztosítását. 
A következő fejlemény a digitális pénzügyi szolgáltatásokhoz igénybe vett eszközök és adatok felhasználásához kapcsolódott. Egyre gyakoribb szakmai kritika érte a nagy adatok, a hátrahagyott adatok hozzáférését és felhasználását. Ezeknek az adatoknak jelentős hányadát birtokosuk tudta nélkül algoritmusok, programozott alkalmazások gyűjtötték össze, de az adatok felhasználása utóbb még akkor is problémákat vetett fel, ha azokat az ügyfél beleegyezésével rögzítették. A BigTech-cégek pedig szolgáltatásaik egy részét adatokért cserébe nyújtják.

A FinTech-szolgáltatások árnyoldalai nőttek, eljött az ideje, hogy a szabályozók és a felügyeletek lépjenek. A potenciális kockázatokra elsőként az FSB hívta fel a figyelmet, megállapítva, hogy a FinTech/BigTech cégek piaci térnyerése megváltoztatja a pénzpiaci struktúrát, felmerülhetnek pénzügyi stabilitási kockázatok, és a gyors, alacsony vagy ingyenes árazású BigTech-szolgáltatások olyan versenyre kényszerítik a hagyományos bankokat, ami múködési kockázatokat eredményez. A feltárt potenciális kockázatok miatt a nemzeti és nemzetközi szabályozók között egyetértés alakult ki, hogy a pénzügyi digitális szolgáltatók, FinTech-cégek tevékenységének megkezdését engedély kiadásához kell kötni. Erre vonatkozóan az Európai Központi Bank licenckiadási útmutatót készített, de az engedélyezés és felügyelet továbbra is nemzeti hatáskörben maradt, miközben összehangolt nemzetközi szabályozásra lenne szükség.

Mivel nyilvánvaló, hogy egy ilyen átfogó szabályrendszer kialakítása csak a távolabbi jövőben várható, megjelent a horizonton egy olyan követelményrendszer, amit nemzetközi egyetértés és együttműködés is támogat. Ez pedig a bizalom és etika, új magatartási formák, a kötelező gondosság új normáinak megkövetelése a FinTech és az azt támogató digitális eszközök világában.

A hagyományos bankok esetében tapasztalat, hogy az etikai kérdések egy válság, megrázkódtatást követő kármentő szabályozás után, a bizalom helyreállításának időszakában kerülnek előtérbe. A FinTech esetében a bizalom építésének szükségessége a kezdeti időszakban érdemben nem merült fel, a szabályozás laza, megengedő volt. Például a regulatory sandboxok elsődleges feladata a FinTech-startupok piacra segítése volt. Ennek keretében a jelentkező és befogadott startupok ideiglenes mentességet kapnak bizonyos szabályozások alól egy bizonyos méretű ügyfélkörre, meghatározott rövid ideig (pl. 6-12 hónap). Ezt követően az innovátornak minden vonatkozó hatályos szabályozást be kell tartania.

A gyors fejlődés azt mutatta, hogy nem elégséges, ha a szabályozás, a tisztességes, etikus magatartás követelménye csak közvetlenül a FinTech- és a digitális pénzügyi szolgáltatókra vonatkozóan terjed ki, elkerülhetetlen a tevékenységükhöz nélkülözhetetlen eszközökre való kiterjesztése is, ide értve a mesterséges intelligenciát, a nagy adatok kezelését. Ebben a helyzetben első helyre került az etikai normák, kódexek alkalmazásának alkalmazása. Azzal, hogy a FinTech etikai követelmények 
a szabályozók elé kerültek, megváltozott a hagyományos sorrendiség, amit az tett lehetővé, hogy a fentiekben bemutatott digitális pénzügyi szolgáltatások egy hosszan tartó, békés gazdasági fejlődés szakaszában mutattak fel piaci térnyerést. A jelenleg alkalmazott etikai, magatartási normák és az átfogó nemzetközi szabályozás hiánya akkor kerül megmérettetésre, ha bekövetkezik egy gazdasági lassulás, recesszió. Szabályrendszerük kialakítása és szigorítása várhatóan akkor gyorsul fel és lesz elkerülhetetlen, akkor alakulhatnak ki kényszerűen az egyenlő versenyfeltételek a hagyományos bankokkal. Az elmúlt évek digitális fejleményeit megtapasztalva azt mondhatjuk, hogy óriási erőket képesek megmozgatni, hatalmas befolyásuk lehet a pénzpiacok mozgására, struktúrájára.

A negyedik ipari forradalom egyik főszereplőjéről szóltunk. A harmadik ipari forradalom főszereplői a gépek voltak, és a mögöttük álló mechanika. Tanulságos a mechanika alaptörvényének akkori meghatározása: „A mechanika az erők hatásáról szóló tan. Az erők hatása testmozgások létrehozása és megakadályozása, meglevő mozgások megváltoztatása, vagy változásának megakadályozásában nyilvánul meg" (Ritter 1879:1). Bár a XIX. századi mechanikai törvényeknek nem volt etikai kódexe, értékrendjük lefordítható a FinTech és az Al nyelvére is.

Végső gondolat: az etikai normák kialakítását a FinTech és BigTech világában nem szabad lebecsülni. Írásunk éppen azt erősíti, hogy szerepük fontos, előkészítik az ellenőrzés és felelősségre vonás lehetőségét, elvi alapot adnak a szükségszerű felügyeleti és szabályozási feladatok megvalósításához, majd a folyamat későbbi szakaszában harmonikus kapcsolat alakulhat ki a hagyományos bankok és a FinTech-szolgáltatók etikai értékrendje között.

\section{Felhasznált irodalom}

Arner, D. W. - Barberis, J. N. - Buckley, R. P. (2015): The Evolution of Fintech: A New PostCrisis Paradigm. Research Working Paper No. 2015/047, University of Hong Kong, Faculty of Law. https://doi.org/10.2139/ssrn.2676553

Bailey, A. (2019): The future of financial conduct regulation. Bloomberg, London, április 23. https://www.fca.org.uk/news/speeches/future-financial-conduct-regulation. Letöltés ideje: 2019. május 22.

Bogusz, C.I. (2019): Digital traces, ethics and insight. Data-driven services in FinTech. In: Teigland,R. - Siri,S. - Larsson, A. - Puertas, A.M. - Bogusz, C.I. (ed.): The Rise and Development of FinTech, Chapter 11. https://doi.org/10.4324/9781351183628-12

Brown, S. (2019): Facebook is dangerous. Senate Hearing on Facebook Digital Currency Ranking Member Brown Opening Statement, július 16. https://www.brown.senate.gov/ newsroom/press/release/brown-opening-statement-at-facebook-hearing 
Busch, R. (2018): How can we build trust in the digital age? World Economic Forum. https:// www.weforum.org/agenda/2018/01/trust-digital-age-cybersecurity-roland-busch/. Letöltés ideje: 2019. május 22.

ECB (2018): Guide to assessments of fintech credit institution licence applications. Banking Supervision, European Central Bank. https://www.bankingsupervision.europa.eu/ecb/ pub/pdf/ssm.201803_guide_assessment_fintech_credit_inst_licensing.en.pdf. Letöltés ideje: 2019. május 22.

ESA (2019): European Supervisory Authorities: How will the ESA promote FinTech? Brussels, 1 April.

Európai Bizottság (2019a): Ethics Guidelines for Trustworthy Artificial Intelligence. European, 8. April, 2019. https://ec.europa.eu/digital-single-market/en/news/ethics-guidelinestrustworthy-ai. Letöltés ideje: 2019. szeptember 12.

Európai Bizottság (2019b): Mesterséges intelligencia: a Bizottság folytatja az etikai iránymutatásokkal kapcsolatos munkáját. Sajtóközlemény. https://europa.eu/rapid/pressrelease_IP-19-1893_hu.htm. Letöltés ideje: 2019. május 22.

EBF (2018): European Banking Federation: Financing the Europe of Tomorrow. A vision for European policy makers, banks in a changing world. https://www.ebf.eu/wp-content/ uploads/2018/09/Financing-the-Europe-of-tomorrow-a-vision-for-policymakers-banksand-markets-in-a-changing-world-September-2018.pdf. Letöltés ideje: 2019. szeptember 8.

Fáykiss Péter - Papp Dániel - Sajtos Péter - Tőrös Ágnes (2018): A FinTech-innovációk ösztönzésének szabályozói eszközei: Innovation Hub és Regulatory Sandbox a nemzetközi gyakorlatban. Hitelintézeti Szemle, 17(2): 43-67. http://doi.org/10.25201/HSZ.17.2.4367

FSB (2019): Financial Stability Board: FinTech and market structure in financial services: Market developments and potential financial stability implications. Február 14. https:// www.fsb.org/wp-content/uploads/P140219.pdf. Letöltés ideje: 2019. május 22.

Fleming, S. (2018): We no longer have faith in technology to solve global issues. World Economic Forum. https://www.weforum.org/agenda/2018/10/digital-distrust-we-relosing-faith-in-technology-to-solve-the-world-s-problems/. Letöltés ideje: 2019. május 22.

Guillén, M. F. - Reddy, S. (2018): We know ethics should inform Al. But which ethics? https:// www.weforum.org/agenda/2018/07/we-know-ethics-should-inform-ai-but-which-ethicsrobotics/. Letöltés ideje: 2019. május 22.

Kerényi Ádám - Molnár Júlia (2017): A FinTech-jelenség hatása - Radikális változás zajlik a pénzügyi szektorban? Hitelintézeti Szemle, 16(3): 32-50. http://doi.org/10.25201/ HSZ.16.3.3250 
Kerényi Ádám - Müller János (2019): Szép új digitális világ? - A pénzügyi technológia és az információ hatalma. Hitelintézeti Szemle, 18(1): 5-33. http://doi.org/10.25201/ HSZ.18.1.533

Koslowski, P. (2011): The Ethics of Banking. Conclusions from the Financial Crisis. Springer. https://doi.org/10.1007/978-94-007-0656-9

Loeger, H. (2019): Austria may launch Fintech Regulatory Sandbox. https://www.devereaustria.eu/news/Austria-may-launch-Fintech-Regulatory-Sandbox. Letöltés ideje: 2019. május 22.

Magyar Bankszövetség (2015): Aktualizált Magatartási Kódex a lakosság részére hitelt nyújtó pénzügyi szervezetek ügyfelekkel szembeni tisztességes magatartásáról. https:// docplayer.hu/814270-Aktualizalt-magatartasi-kodex-a-lakossag-reszere-hitelt-nyujtopenzugyi-szervezetek-ugyfelekkel-szembeni-tisztesseges-magatartasarol.html. Letöltés ideje: 2019. május 22.

MNB (2019): Nemzetközi Fintech hatósági csoporthoz csatlakozott az MNB. MNB sajtóközlemény, 2019. január 31. https://www.mnb.hu/sajtoszoba/sajtokozlemenyek/2019evi-sajtokozlemenyek/nemzetkozi-fintech-hatosagi-csoporthoz-csatlakozott-az-mnb. Letöltés ideje: 2019. május 22.

Ritter Ágost (1879): Műszaki mechanika. Franklin Társulat, Budapest.

Villa, J. (2015): Ethics in Banking. The Role of Moral Values and Judgements in Finance. Palgrave Macmillan. 